\title{
Physicochemical and Functional Modifications of Hemp Protein Concentrate by the Application of Ultrasonication and $\mathrm{pH}$ Shifting Treatments
}

\author{
Ozan Kahraman *, Greg E. Petersen and Christine Fields
}

Citation: Kahraman, O.; Petersen, G.E.; Fields, C. Physicochemical and Functional Modifications of Hemp Protein Concentrate by the Application of Ultrasonication and pH Shifting Treatments. Foods 2022, 11, 587. https://doi.org/10.3390/ foods 11040587

Academic Editor: Christine Scaman

Received: 31 January 2022

Accepted: 16 February 2022

Published: 18 February 2022

Publisher's Note: MDPI stays neutral with regard to jurisdictional claims in published maps and institutional affiliations.

Copyright: (C) 2022 by the authors. Licensee MDPI, Basel, Switzerland. This article is an open access article distributed under the terms and conditions of the Creative Commons Attribution (CC BY) license (https:// creativecommons.org/licenses/by/ $4.0 /$ )
Applied Food Sciences Inc., 8708 S. Congress Avenue STE B290, Austin, TX 78745, USA; gpetersen@appliedfoods.com (G.E.P.); cfields@appliedfoods.com (C.F.)

* Correspondence: ozan@appliedfoods.com

\begin{abstract}
According to the Food and Agriculture Organization (FAO), protein demand is expected to increase globally by around $40 \%$ by 2030 as a response to the world's population growth. Due to their clean label, vegan or vegetarian based applications, nutritional value, and cost-efficient properties, plant-based proteins have been widely studied. However, most of the alternatives currently found in the market have some challenges because of their poor solubility, emulsifying, gelling, and foaming attributes. Hemp seed protein has gained increasing attention due to its unique amino acids and fatty acids profiles. In this study, commercial HPC mixtures were adjusted to $\mathrm{pH} 2$, $4,6,8,10$, and 12 followed by ultrasonication (US) for $5 \mathrm{~min}$ ( $5 \mathrm{~s}$ on: $5 \mathrm{~s}$ off) and incubated for an hour before neutralizing to $\mathrm{pH}$ 7. Following the treatments, the samples were analyzed for their hydrodynamic diameter, conductivity, zeta potential, polydispersity index, surface hydrophobicity, solubility, electrophoresis (SDS-PAGE), free sulfhydryl group, and optical characteristics. The samples treated with ultrasound at $\mathrm{pH} 8$ and 10 significantly $(p<0.05)$ enhanced the solubility of the hemp seed protein by $12.12 \%$ and $19.05 \%$, respectively. Similarly, the samples treated with ultrasonication and $\mathrm{pH}$ shifting at $\mathrm{pH} 6,8$, and 10 also significantly increased the amount of free sulfhydryl content $(p<0.05)$ to 41.6, 58.72, and $46.54 \mathrm{mmol} / \mathrm{g}$ from $32.8 \mathrm{mmol} / \mathrm{g}$, respectively. This study shows that the application of ultrasonication and $\mathrm{pH}$ shifting is a promising alternative method to modify the functional properties of HPC and widen their applications in the food, cosmetics, and pharmaceutical industries.
\end{abstract}

Keywords: hemp protein; ultrasound; $\mathrm{pH}$ shifting; SDS-PAGE; free sulfhydryl group

\section{Introduction}

Proteins have a fundamental role both in sustaining human life and food products and they can be derived from animals or plants. They are structural macromolecules accounting for almost $75 \%$ (d.b.) of total body weight which are broken down to amino acids and used to synthesize hormones and enzymes, form bones, support the immune system, and build other functional compounds, such as antibodies [1]. In addition to their important roles in health and nutrition, proteins have many functional properties (water holding, emulsifying, foaming, gelation, etc.) which make them useful as multipurpose ingredients for many applications and/or formulations in food, animal feed, pharmaceutical, and chemical industries [2].

According to the Food and Agriculture Organization (FAO), the world population is projected to increase almost $70 \%$ by 2050 and this growing population will result in an increased demand for protein. It is expected that animal and plant sourced protein demand globally will increase 33 and $43 \%$, respectively [3]. The awareness about the challenge of the growing world population encourages scientists to search for sustainable and economically feasible alternatives for animal-based proteins. It has been understood that livestock farming, and hence animal-based products have a serious impact on today's environmental problems, such as climate change, greenhouse gas emissions, biodiversity 
loss, and pollution, which make them unsustainable and impractical [4]. Therefore, recently, plant-based proteins are increasingly being used as an alternative protein source in different industries. There are many oil crops that can be used as protein sources due to their high protein content, such as soybean, canola, flax seed, cotton seed, and sunflower. Hemp seeds have gained a growing interest in the food industry because of its rich nutrient composition and functionality. It is harvested worldwide and is economical due to its lower water consumption and easy cultivation compared to other plants. It is also known as a renewable energy source because of its high biomass and energy concentration. Hemp seeds mainly consist of $30-35 \%$ oil, $20-25 \%$ protein, and $25-30 \%$ carbohydrates. Due to its essential fiber, amino acid, and unsaturated fatty acid contents, hemp seed carries a great potential to be an alternative protein source for human consumption [5]. Previous studies reported that hemp protein contains all nine essential amino acids and has a comparable amino acid profile to well-known high-quality proteins, such as casein, soy protein, and egg white protein [6]. It has been also shown that hemp protein is abundant in glutamic acid and arginine, which are not commonly found in other oil seed proteins. Arginine has a considerable role in ammonia detoxification, fetal growth, and the maintenance of normal blood pressure, while glutamic acid has a vital role as a neurotransmitter in the brain $[7,8]$. The amino acid score for hemp protein is between 0.5 and 0.62 , with lysine being the first limiting amino acid, followed by leucine and tryptophan $[9,10]$. Moreover, compared to cereal grains such as whole wheat, hemp protein has a higher protein digestibility-corrected amino acid score (PDCAAS) value, which is close to the values of some legume proteins, such as beans and lentils [9].

Despite its nutritious composition, hemp seed protein has a limited utilization in the food and pharmaceutical industries due to its poor functional properties, which is a common problem in many plant-based proteins. Various physical, chemical, and enzymatic processing methods have been employed to overcome these poor functional properties [11-13]. Ultrasonication is a novel processing technology which can ameliorate the functional deficiencies of hemp protein by modifying its structural properties. The application of power ultrasonication leads to different cavitation activities, including shock waves, shear forces, and localized high pressure and temperature in the medium [14]. This phenomenon contributes to the modification of the structural and functional properties of proteins, such as particle size, surface hydrophobicity, solubility, etc. [15-20]. A recent systematic review study also revealed that ultrasonication treatment improved not only the solubility, but also the emulsifying activity, foam stability, and foaming capacity of different plant-based proteins [21]. In addition to ultrasonication treatment, $\mathrm{pH}$ shifting is another process that could affect the protein structure by folding and unfolding at different $\mathrm{pH}$ levels. Previous studies have declared that $\mathrm{pH}$ shifting treatments could alter the globular structure of proteins, resulting in an increased amphipathic property of the proteins $[20,22,23]$. There are also several studies in which $\mathrm{pH}$ shifting was used as a pretreatment process or combined with ultrasonication in order to advance the functional properties of plant-based proteins such as soy, pea, and rice protein [22,24-26].

In this study, the main objective was to investigate the effects of ultrasonication combined with $\mathrm{pH}$ shifting treatments on the physicochemical properties of hemp protein concentrate. The possible outcome of this research can provide a potential solution to improve and modify the functional attributes of hemp protein concentrate which would increase its application in a broad range of fields, including food, cosmetics, and pharmaceutical industries.

\section{Materials and Methods}

\subsection{Materials}

Hemp seed protein concentrate samples (76\% hemp protein (d.m.)) were provided by Applied Food Sciences Inc. (Austin, TX, USA). This commercial HPC was chosen as the starting medium for the experiments and stored at room temperature before use. All other chemicals were purchased from Sigma-Aldrich (St. Louis, MO, USA), Fisher Scientific 
(Pittsburgh, PA, USA), and Bio-Rad (Hercules, CA, USA). All chemicals used in this study were analytical or higher grade.

\section{2. $p H$ Shifting and Ultrasonication Treatments}

The HPC dispersions were prepared by dissolving $6 \mathrm{~g}$ of HPC in $200 \mathrm{~mL}$ of deionized water in a $250 \mathrm{~mL}$ beaker and mixed for $30 \mathrm{~min}$ at room temperature with a magnetic stirrer, followed by homogenization for $5 \mathrm{~min}$ at 10,000 rpm (Model 850, Thermo Fisher Scientific, Waltham, MA, USA). Three treatments were applied to HPC dispersions: $\mathrm{pH}$ shifting alone, ultrasonication alone, and ultrasonication and $\mathrm{pH}$ shifting combined. The non-treated but only stirred sample was used as the control.

The ultrasonication and $\mathrm{pH}$ shifting treatments were applied to HPC dispersions following the methods of Lee et al. [24] and Jiang et al. [26] with slight modifications. A VibraCell VC750 ultrasonic processor (Sonics \& Materials, Inc., Newtown, CT, USA) was used to apply ultrasonication treatment at $20 \mathrm{kHz}$ and $750 \mathrm{~W}$. The acoustic energy was transmitted into HPC dispersions using a $13 \mathrm{~mm}$ diameter probe. An ice bath was utilized to keep the sample temperature below $40^{\circ} \mathrm{C}$ and to prevent possible overheating due to ultrasonication that could lead to protein denaturation. Duty cycle of sonication pulse was set at $100 \%$ amplitude ( $5 \mathrm{~s}$ on: $5 \mathrm{~s}$ off). During the ultrasonication alone treatment, the HPC dispersions were sonicated for $5 \mathrm{~min}$, and then were kept at room temperature for an hour. In the $\mathrm{pH}$ shifting alone treatments, the $\mathrm{pH}$ of the HPC dispersion samples were adjusted to $\mathrm{pH} 2,4,6,8,10$, or 12 with $1 \mathrm{M} \mathrm{NaOH}$ or $1 \mathrm{M} \mathrm{HCl}$ at room temperature. Following the one-hour incubation at room temperature, their $\mathrm{pH}$ was adjusted back to $\mathrm{pH} 7$. Finally, in the ultrasonication and $\mathrm{pH}$ shifting combined treatments, the HPC dispersion samples were exposed to sonication for $5 \mathrm{~min}$ immediately after they were treated with $\mathrm{pH}$ shifting. All the treated samples were finally centrifuged at $12,400 \times g$ at $20^{\circ} \mathrm{C}$ for $20 \mathrm{~min}$ (Sorvall Legend XTR centrifuge, Thermo Scientific, Osterode am Harz, Germany). The supernatants were collected for further analysis.

\subsection{Acoustic Energy Determination}

As ultrasound goes through the liquid matrix, some of the sonication power transforms into heat energy. The amount of lost acoustic power (power loss) was calculated as described in the study of Guzel et al. [27]. The temperature was recorded during the first $30 \mathrm{~s}$. The rate of temperature increase was then calculated from the slope of temperature versus time graph created using the recorded temperature data. The power loss was calculated by using Equation (1):

$$
P=m C_{p} d T / d t
$$

where $m$ is the mass of the liquid used (g) and $C p$ is the heat capacity of the liquid (in $\mathrm{J} \mathrm{g}^{-1}{ }^{\circ} \mathrm{C}^{-1}$ ).

The unit of power loss is watts per unit volume of the sonicated solution $\left(\mathrm{W} / \mathrm{cm}^{3}\right)$. The determined lost sonication power in the liquid was $13.25 \pm 0.18 \mathrm{~W}$.

\subsection{Hydrodynamic Diameter, Conductivity, Zeta-Potential, and Polydispersity Index}

The hydrodynamic diameter $(\mu \mathrm{m})$, conductivity $(\mathrm{mS} / \mathrm{cm})$, zeta potential $(\mathrm{mV})$, and polydispersity index (\%) of the HPC dispersions were measured by dynamic light scattering (DLS) and electrophoretic light scattering (ELS) (Litesizer 500, Anton Paar, Graz, Austria) with a $40-\mathrm{mW}$ semiconductor laser with a wavelength of $658 \mathrm{~nm}$, and the detection angle of back $\left(175^{\circ}\right)$, side $\left(90^{\circ}\right)$, and forward $\left(15^{\circ}\right)$.

The random movement and speed of particles in a liquid medium depends on particle size. The DLS method measures this constant movement of suspended particles in a solution. This movement or motion is also known as Brownian movement/motion [28]. In this research, the hydrodynamic diameter and polydispersity index were measured using a $2 \mathrm{~mL}$ disposable cuvette at $25^{\circ} \mathrm{C}$.

The zeta potential of HPC dispersions was analyzed using the Kalliope 2.2 software at $25 \pm 0.1{ }^{\circ} \mathrm{C}$ with an equilibration time of $1 \mathrm{~min}$. An amount of $1 \mathrm{~mL}$ of each sample was 
placed in an omega cuvette without any air bubbles. Three replicates were carried out for each sample, with 100 scans per individual measurement.

\subsection{Optical Characterizations and Turbidity}

The turbidity of the HPC samples was carried out on a Cytation 5 multimode microplate reader (BioTek Instruments, Inc., Winooski, VT, USA), using 96-well polystyrene microplates. Distilled water was used as the blank and the absorbance was measured at $600 \mathrm{~nm}$. The average of the three replications were reported.

Changes in the color of treated and untreated HPC dispersions were monitored with a Vista colorimeter (HunterLab, VA, USA) based on the CIE $\mathrm{L}^{*}, \mathrm{a}^{*}$, and $\mathrm{b}^{*}$ color coordinates. The $\mathrm{L}^{*}$ indicates brightness/darkness index (0 to 100/black to white), $\mathrm{a}^{*}$ indicates redness/greenness (' + ' values for red, ' ${ }^{\prime}$ ' values for green), and $b^{*}$ indicates yellowness/blueness ('+' values for yellow, ' - ' values for blue). An amount of $2 \mathrm{~mL}$ of sample was placed in a disposable cuvette and three-color readings $\left(\mathrm{L}^{*}, \mathrm{a}^{*}\right.$, and $\mathrm{b}^{*}$ values) per sample were taken at room temperature. The average $\mathrm{L}^{*}, \mathrm{a}^{*}$, and $\mathrm{b}^{*}$ values were reported. These values were used to calculate the following color parameters:

Total color change $(\Delta E)$ represents the level of total color alteration between the initial and final samples. Equation (2) was used to calculate the total color change $(\Delta E)$ of the dispersions:

$$
\Delta E=\sqrt{\left(\Delta \mathrm{L}^{*}\right)^{2}+\left(\Delta \mathrm{a}^{*}\right)^{2}+\left(\Delta \mathrm{b}^{*}\right)^{2}}
$$

where $\Delta \mathrm{L}^{*}, \Delta \mathrm{a}^{*}$, and $\Delta \mathrm{b}^{*}$ were the difference of individual $\mathrm{L}^{*}, \mathrm{a}^{*}, \mathrm{~b}^{*}$ color readings from the control sample [29].

\subsection{Surface Hydrophobicity Determination}

Surface hydrophobicity was measured following the method described by Kato and Nakai [30] and Wang et al. [11] with slight modifications. Briefly, 1-Anilino-8-naphthalene sulphonate (ANS) (Sigma-Aldrich, St. Louis, MO, USA) was utilized as the fluorescence probe. An $8 \mathrm{mM}$ ANS stock solution was prepared in $0.01 \mathrm{M}, \mathrm{pH} 7$ phosphate buffer. Each HPC sample was diluted to five series of concentrations ranging from 0.025 to $0.2 \mathrm{mg} / \mathrm{mL}$. Then, $20 \mu \mathrm{L}$ of ANS was added into $4 \mathrm{~mL}$ of sample. The fluorescence intensity was measured (excitation and emission were $340 \mathrm{~nm}$ and $440 \mathrm{~nm}$, respectively) with a Cytation 5 multimode microplate reader (BioTek Instruments, Inc., Winooski, VT, USA). The initial slope of fluorescence intensity versus protein concentration $(\mathrm{mg} / \mathrm{mL})$ plot of the serial dilutions were used to calculate the surface hydrophobicity.

\subsection{Protein Quantification (Solubility) and Electrophoresis (SDS-PAGE)}

The solubility of the HPC samples was determined with the Pierce BCA Protein Assay Kit (Thermo Scientific) based on the bicinchoninic acid (BCA) method using bovine serum albumin (BSA) as the standard. The samples were centrifuged at $12,000 \times g$ for $15 \mathrm{~min}$, and the supernatant was collected and diluted 1:10 with water. The standard curve was prepared using $2 \mathrm{mg} / \mathrm{mL}$ BSA stock solution at different concentrations levels $(50 \mu \mathrm{g} / \mathrm{mL}-400 \mu \mathrm{g} / \mathrm{mL})$. After that, $25 \mu \mathrm{L}$ standards and/or samples were loaded in triplicate into a 96 well microtiter plate and $200 \mu \mathrm{L}$ BCA reagent (50 parts BCA reagent A to 1-part $B C A$ reagent $B$ ) was added to each well. The microplate was mixed and incubated at $37^{\circ} \mathrm{C}$ for $30 \mathrm{~min}$. Following incubation, the plate was allowed to cool for approximately $10 \mathrm{~min}$, then the absorbance was read at $562 \mathrm{~nm}$ with a multimode microplate reader (Cytation 5, BioTek Instruments, Inc., Winooski, VT, USA). The protein concentrations were calculated using the BSA standard curve $\left(R^{2}=0.996\right)$. The amount of soluble protein was represented as $\mathrm{mg} / \mathrm{mL}$.

The samples were evaluated by SDS-PAGE, as described by Tang et al. [6] with modifications, on $8-16 \%$ precast gels (Mini-Protean TGX Stain-Free Protein Gel, Bio-Rad Laboratories, Hercules, CA, USA) using a Mini Protean III Electrophoresis Cell (Bio-Rad Laboratories, Hercules, CA, USA). The samples were diluted (1:30 $v / v)$ in 1X Laemmli sam- 
ple buffer (Bio-Rad Laboratories, Hercules, CA, USA) in the presence (reducing condition) or absence (non-reducing condition) of $50 \mathrm{mM}$ DTT and denatured at $95^{\circ} \mathrm{C}$ for $5 \mathrm{~min}$. The samples $(4 \mu \mathrm{L})$ and markers $(4 \mu \mathrm{L})$ were loaded on the gel and electrophoresed at a constant voltage $(145 \mathrm{~V})$ for approximately $50 \mathrm{~min}$ at room temperature. Following separation, the gels were stained with Coomassie Brilliant Blue R-250 Staining Solution (Bio-Rad Laboratories, Hercules, CA, USA) overnight and destained using reverse osmosis water. The gels were imaged using a Bio-Rad ChemiDoc MP (Bio-Rad Laboratories, Hercules, CA, USA).

\subsection{Free Sulfhydryl Group Analysis}

The free sulfhydryl group content of the samples was analyzed following the method of Beveridge et al. [31] and manufacturer's instructions with some modifications. 5,5'Dithio-bis-(2-Nitrobenzoic Acid) (DTNB) and Ellman's reagent (Thermo Fisher Scientific, Waltham, MA, USA) were utilized to determine the content of the free sulfhydryl group in the samples. Sodium phosphate buffer $(0.1 \mathrm{M}, \mathrm{pH} 8.0)$ was used to dilute the protein solution to a certain concentration. L-Cysteine hydrochloride (Alfa Aesar, Tewksbury, MA, USA) was used as a standard. Dilutions of cysteine $(0.25-1.5 \mathrm{mM})$ sodium phosphate buffer $(0.1 \mathrm{M}, \mathrm{pH} 8.0)$ were prepared to plot a standard curve. An amount of $50 \mu \mathrm{L}$ of Ellman's reagent solution $(4 \mathrm{mg} / \mathrm{mL})$ was added in the mixture of $250 \mu \mathrm{L}$ of protein sample and $2.5 \mathrm{~mL}$ of sodium phosphate buffer. After incubation at room temperature for $15 \mathrm{~min}$, the absorbance was measured in triplicates at $412 \mathrm{~nm}$ using a multimode microplate reader (Cytation 5, BioTek Instruments, Inc., Winooski, VT, USA). The free sulfhydryl group content was expressed as $\mu \mathrm{mol} / \mathrm{g}$ protein.

\subsection{Statistical Analysis}

All experiments were conducted in triplicates. The results were expressed as mean value \pm standard deviation (S.D.). Rstudio software was used to conduct the statistical analysis of the collected data. Differences between the treatments were assessed by running One-way ANOVA, followed by conducting Fisher's least significant difference (LSD) test. Significant differences among the samples were detected at $p<0.05$.

\section{Results and Discussion}

\subsection{Hydrodynamic Diameter, Zeta-Potential, Conductivity and Polydispersity Index}

The hydrodynamic diameter of proteins has a crucial effect on the functional and physical properties of proteins, such as the solubility, emulsification, foaming capacity, and gel properties [32]. The hydrodynamic diameter, conductivity, and polydispersity index of treated and non-treated HPC dispersions are shown in Table 1. According to the results, after the combined treatment of $\mathrm{pH}$ shifting at $\mathrm{pH} 4$ and ultrasonication, the particle size of HPC dispersions decreased significantly $(p<0.05)$ from $1.05 \pm 0.05 \mu \mathrm{m}$ to $0.33 \pm 0.02 \mu \mathrm{m}$, and their polydispersity index values also showed a significant reduction $(p<0.05)$ from $55.9 \pm 1.2 \%$ to $12.1 \pm 0.02 \%$. Moreover, regardless of targeted $\mathrm{pH}$ levels, combining $\mathrm{pH}$ shifting with ultrasonication resulted in lower hydrodynamic diameter than control and $\mathrm{pH}$ shifting alone treatments. HPC dispersions at different $\mathrm{pH}$ alone treatments unfolds and partially disaggregates, while application of ultrasonication may further disrupt the interactions between protein molecules by ultrasonic physical forces (shear forces, turbulent forces, cavitational forces, etc.) $[17,19,33]$ and escalate these changes. Therefore, the hydrodynamic diameter of samples treated with the combination of $\mathrm{pH}$ shifting and ultrasonication treatments had smaller particle size than the non-sonicated samples. These results agree with earlier studies. In the study of Jiang et al. [25], the particle size of pea protein isolate treated with ultrasonication was two times smaller than that of the control. Similarly, the application of ultrasonication and $\mathrm{pH}$ shifting significantly reduced $(p<0.05)$ the particle size of rice protein $(219.8-248.8 \mathrm{~nm})$ compared to the control $(486.4 \mathrm{~nm})$ [34]. 
Table 1. Hydrodynamic diameter, polydispersity index, and conductivity of non-treated and treated HPC samples.

\begin{tabular}{cccc}
\hline & $\begin{array}{c}\text { Hydrodynamic } \\
\text { Diameter }(\boldsymbol{\mu m})\end{array}$ & $\begin{array}{c}\text { Polydispersity Index } \\
(\mathbf{\%})\end{array}$ & $\begin{array}{c}\text { Conductivity } \\
(\mathbf{m S} / \mathbf{c m})\end{array}$ \\
\hline Control & $1.048 \pm 0.05^{\mathrm{a}}$ & $55.90 \pm 1.2^{\mathrm{a}}$ & $0.958 \pm 0.004^{\mathrm{k}}$ \\
\hline pH2 & $0.945 \pm 0.021^{\mathrm{b}}$ & $46.20 \pm 0.14^{\mathrm{b}}$ & $1.143 \pm 0.010^{\mathrm{i}}$ \\
\hline pH4 & $0.920 \pm 0.028^{\mathrm{b}}$ & $42.90 \pm 0.14^{\mathrm{d}}$ & $1.302 \pm 0.025^{\mathrm{f}}$ \\
\hline pH6 & $0.925 \pm 0.007^{\mathrm{b}}$ & $46.80 \pm 0.42^{\mathrm{b}}$ & $1.210 \pm 0.006^{\mathrm{h}}$ \\
\hline pH8 & $0.905 \pm 0.007^{\mathrm{b}}$ & $42.30 \pm 0.28^{\mathrm{d}}$ & $1.025 \pm 0.001^{\mathrm{j}}$ \\
\hline pH10 & $0.915 \pm 0.007^{\mathrm{b}}$ & $40.80 \pm 0.42^{\mathrm{e}}$ & $1.272 \pm 0.026^{\mathrm{fg}}$ \\
\hline pH12 & $0.925 \pm 0.007^{\mathrm{b}}$ & $45.00 \pm 0.28^{\mathrm{c}}$ & $1.221 \pm 0.016^{\text {gh }}$ \\
\hline US_Only & $0.370 \pm 0.014^{\mathrm{def}}$ & $13.40 \pm 0.14^{\mathrm{g}}$ & $2.906 \pm 0.021^{\mathrm{b}}$ \\
\hline US + pH2 & $0.340 \pm 0.014^{\mathrm{ef}}$ & $16.35 \pm 0.21^{\mathrm{f}}$ & $2.186 \pm 0.006^{\mathrm{e}}$ \\
\hline US + pH4 & $0.33 \pm 0.02^{\mathrm{f}}$ & $12.10 \pm 0.02^{\mathrm{h}}$ & $2.275 \pm 0.005^{\mathrm{d}}$ \\
\hline US + pH6 & $0.400 \pm 0.014^{\mathrm{d}}$ & $16.30 \pm 0.28^{\mathrm{f}}$ & $2.329 \pm 0.005^{\mathrm{c}}$ \\
\hline US + pH8 & $0.380 \pm 0.014^{\mathrm{de}}$ & $14.30 \pm 0.28^{\mathrm{g}}$ & $2.962 \pm 0.010^{\mathrm{a}}$ \\
\hline US + pH10 & $0.425 \pm 0.021^{\mathrm{d}}$ & $16.95 \pm 0.21^{\mathrm{f}}$ & $2.203 \pm 0.003^{\mathrm{e}}$ \\
\hline US + pH12 & $0.510 \pm 0.014^{\mathrm{c}}$ & $17.30 \pm 0.14^{\mathrm{f}}$ & $2.169 \pm 0.004^{\mathrm{e}}$ \\
\hline
\end{tabular}

$\overline{\mathrm{a}-\mathrm{k}}$ Treatment means with the same letter in each sample are not significantly different $(p>0.05)$.

With respect to polydispersity index, all ultrasonication treated HPC dispersions (ranging from 12.10 to $17.30 \%$ ) showed significantly lower values than the control (55.90\%) and $\mathrm{pH}$ alone treated dispersions (ranging from 40.88 to $46.80 \%$ ). Zhang et al. [34] also reported that the polydispersity of rice protein was reduced almost by $40 \%$ with the application of sonication at $20 \mathrm{kHz}$ frequency for $60 \mathrm{~min}$ at $50^{\circ} \mathrm{C}$. This might be related to the intensification of the cavitation and mechanical effects of ultrasonication treatments [20]. The reduction in particle size can enhance the interaction between water and protein molecules leading to an increase in solubility $[12,35,36]$.

Zeta potential is widely used to characterize and measure the surface charges of protein molecules and the strength of repulsion or attraction between particles based on electrophoretic mobility technique [18]. As large repulsive forces between particles result in high absolute zeta potential values, a more stable system can be achieved with small, dispersed particles [34]. As it can be seen in Figure 1, the absolute value of zeta potential increased with an increasing $\mathrm{pH}$ level both in $\mathrm{pH}$ shifting alone and $\mathrm{pH}$ shifting with ultrasonication treatments, except at acidic $\mathrm{pH}$ levels during $\mathrm{pH}$ shifting alone treatments. The absolute zeta potential value of ultrasonication treated HPC dispersion samples raised significantly $(p<0.05)$ from $[15.4 \pm 1.28] \mathrm{mV}$ to $[29.4 \pm 1.41] \mathrm{mV}$ compared to the control. This might be explained with the cavitation effect of ultrasonication on the protein structure, which causes breakdowns and allows more charges on the molecules [32]. Similarly, Shen et al. [18] observed that the application of ultrasonication significantly increased $(p<0.05)$ the absolute zeta potential of whey proteins from $14.9 \mathrm{mV}$ to $27.94 \mathrm{mV}$ at $20 \mathrm{kHz}$ frequency for $20 \mathrm{~min}$ (10 s:5 s off/on cycles). On the other hand, the decreasing trend in absolute zeta potential values at the acidic $\mathrm{pH}$ levels during $\mathrm{pH}$ shifting alone treatments might be because of the change in ionization degree of the surface groups in HPC dispersions [32]. 


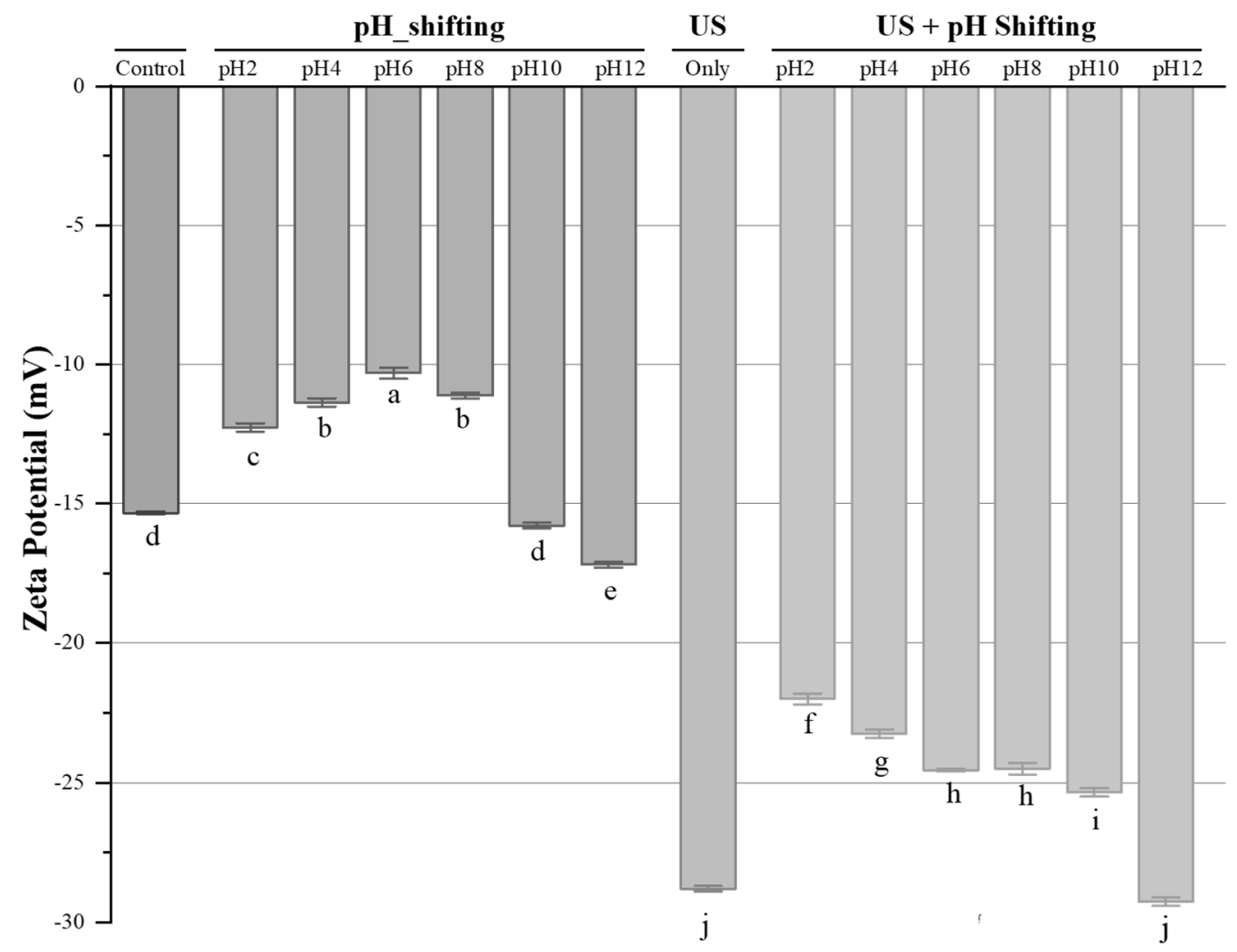

Figure 1. The zetapotential of non-treated and treated HPC samples. ${ }^{a-j}$ Treatment means with the same letter in each sample are not significantly different $(p>0.05)$.

The conductivity of protein is an inherent property of dissolved protein particles which depends on the amount of charged ions [17]. In the present study, the conductivity of HPC dispersions did not change significantly $(p>0.05)$ after $\mathrm{pH}$ alone treatments. However, when ultrasonication treatment was applied, the conductivity of HPC samples increased from $0.96 \pm 0.004 \mathrm{mS} / \mathrm{cm}$ to $2.962 \pm 0.01 \mathrm{mS} / \mathrm{cm}$. Jambrak et al. [15,37] also affirmed that ultrasonication can increase the conductivity of whey protein suspensions and soy proteins. This increasing trend might be explained by the formation of radicals due to the localized extreme physical conditions during ultrasonication treatment. These extreme physical conditions could be very high temperatures (up to $5000^{\circ} \mathrm{K}$ ), high pressures (up to $100 \mathrm{MPa})$, or shock waves $[15,37]$.

\subsection{Surface Hydrophobicity}

The interactions of hydrophobic parts have an important role in the solubility, stability, and functionality (foaming, emulsifying, gelling, etc.) of proteins [23]. The effect of different treatments on the surface hydrophobicity value of HPC dispersions is shown in Figure 2. Ultrasonication treatment resulted in a gradual but significant increase in the surface hydrophobicity when the ultrasonication combined with $\mathrm{pH}$ shifting treatment at different $\mathrm{pH}$ levels. The highest surface hydrophobicity was achieved at ultrasonication only treatment, which was $60 \%$ higher than the control. The $\mathrm{pH}$ sifting treatment alone at $\mathrm{pH} 2,4$, and 6 significantly decreased $(p<0.05)$ the surface hydrophobicity to $54.8,68.6$, and 68.9 from 70.1, respectively. Conversely, the $\mathrm{pH}$ shifting treatment alone increased the surface hydrophobicity at $\mathrm{pH} 8,10$, and 12 from 70.1 to $78.6,76.9$, and 78.8, respectively. Moreover, the combination of ultrasonication with $\mathrm{pH}$ shifting treatment at all levels except $\mathrm{pH} 2$, resulted in a further increase of surface hydrophobicity. Parada et al. [38] evaluated the effect of ultrasonication with the frequency of $20 \mathrm{kHz}$ at $20 \%$ and $40 \%$ amplitude for 0 , 1,3 , and 5 min on a squid protein concentrate. In consistence with the present study, they found an upward trend in surface hydrophobicity as the time and amplitude were increased. 
In another study, Mao et al. [23] applied ultrasound at $20 \mathrm{kHz}$ frequency and different power output levels $(200,400,600,800$, and $950 \mathrm{~W})$ for $60 \mathrm{~min}(2 \mathrm{~s}: 2 \mathrm{~s}$ off/on cycles) to cod protein samples and detected the similar trends in increasing ultrasonic power.

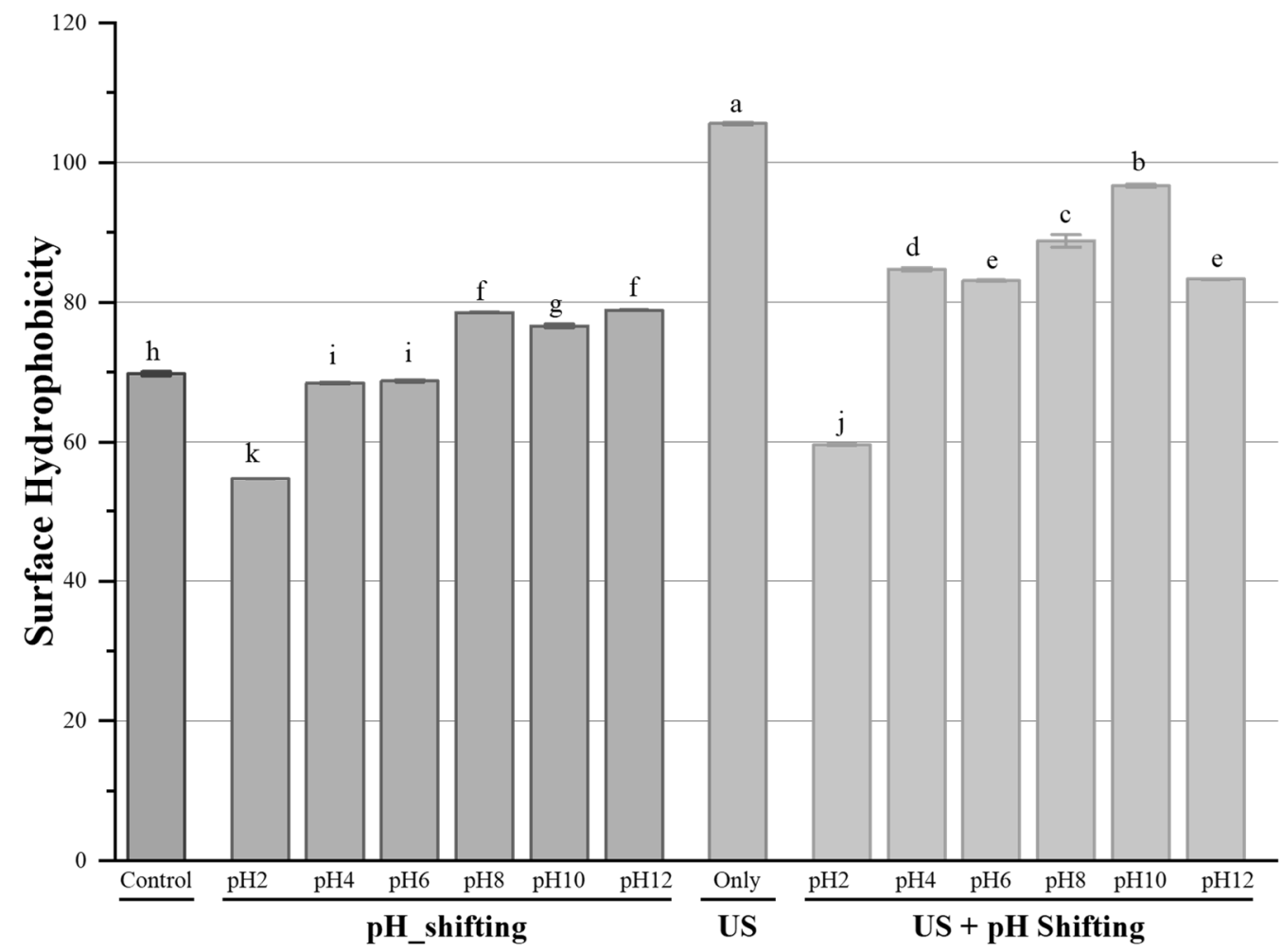

Figure 2. The surface hydrophobicity of non-treated and treated HPC samples. ${ }^{a-k}$ Treatment means with the same letter in each sample are not significantly different $(p>0.05)$.

The increase in surface hydrophobicity might be because of the unfolding of protein structure after the $\mathrm{pH}$ shifting treatments. The ultrasonication application could further unfold the HPC, causing more exposure and relocation of hydrophobic groups at the surface of proteins $[34,39,40]$. The increase on surface hydrophobicity can facilitate a better formation of protein gel with more dense and compact properties in order to reinforce hydrophobic interactions [41].

\subsection{Protein Quantification (Solubility) and Electrophoresis (SDS-PAGE)}

Solubility is one of the most important key indicators of the physicochemical and functional properties of proteins $[39,42]$. Therefore, it has a crucial role in exploring the applicability of plant proteins in different industries [26]. The effects of different methods on the solubility of HPC are shown in Table 2. The solubility of HPC samples at pH 2, 4, and 6 significantly decreased $(p<0.05)$ compared to the control. This might be because the water interaction ability of the samples might be decreased at these $\mathrm{pH}$ levels due to the alterations in some polar compounds, such as carboxyl and amide groups [43]. Compared to the control, $\mathrm{pH}$ shifting treatment at $\mathrm{pH} 8$ and $\mathrm{pH} 10$ slightly increased the solubility of samples by $1.31 \%$ and $0.55 \%$, respectively, although treatments with ultrasonication process at $\mathrm{pH} 8$ and $\mathrm{pH} 10$ significantly $(p<0.05)$ enhanced the solubility of HPC by $12.12 \%$ and $19.05 \%$, respectively. This behavior was also $\mathrm{pH}$ dependent, and the effect of combined treatment was the lowest at $\mathrm{pH} 4$ and $\mathrm{pH} 6$ with a less increase in solubility. The reason might be the application of ultrasonication resulting in partial openings in the structure of proteins by increasing the surface area, facilitating more protein-water interactions and better solubility. Jiang et al. [44] also reported that an ultrasonication treatment applied at $20 \mathrm{kHz}$ and $300 \mathrm{~W}$ for 12 min increased the solubility of black bean 
protein isolate compared to the untreated sample. Similarly, in the study of Huang et al. [42], the solubility of soybean protein isolate increased more than $156 \%$ over the control sample with a combined treatment of ultrasonication $(20 \mathrm{kHz}, 200 \mathrm{~W}, 10 \mathrm{~min}$ ) and pH shifting (at $\mathrm{pH} 3$ ) and reached to $80.9 \%$.

Table 2. Free S-S content, solubility, and turbidity of non-treated and treated HPC samples.

\begin{tabular}{cccc}
\hline & Free S-S (umol/g) & Solubility (ug/mL) & Turbidity \\
\hline Control & $32.8 \pm 0.212^{\mathrm{f}}$ & $1442.75 \pm 0.35^{\mathrm{f}}$ & $0.222 \pm 0.001^{\mathrm{e}}$ \\
\hline $\mathrm{pH} 2$ & $24.45 \pm 0.212^{\mathrm{j}}$ & $1040.65 \pm 0.21^{\mathrm{n}}$ & $0.040 \pm 0.001^{\mathrm{k}}$ \\
\hline $\mathrm{pH} 4$ & $20.80 \pm 0.424^{\mathrm{k}}$ & $1312.65 \pm 0.35^{\mathrm{l}}$ & $0.052 \pm 0.001^{\mathrm{j}}$ \\
\hline $\mathrm{pH} 6$ & $27.70 \pm 0.141^{\mathrm{h}}$ & $1378.25 \pm 0.35^{\mathrm{h}}$ & $0.074 \pm 0.000^{\mathrm{i}}$ \\
\hline $\mathrm{pH} 8$ & $36.65 \pm 0.212^{\mathrm{e}}$ & $1462.10 \pm 0.28^{\mathrm{d}}$ & $0.146 \pm 0.001^{\mathrm{h}}$ \\
\hline $\mathrm{pH} 10$ & $42.35 \pm 0.212^{\mathrm{c}}$ & $1451.40 \pm 0.14^{\mathrm{a}}$ & $0.144 \pm 0.001^{\mathrm{h}}$ \\
\hline pH12 & $13.55 \pm 0.071^{\mathrm{l}}$ & $1069.35 \pm 0.07^{\mathrm{m}}$ & $0.196 \pm 0.001^{\mathrm{f}}$ \\
\hline US_Only & $40.68 \pm 0.042^{\mathrm{d}}$ & $1432.90 \pm 0.14^{\mathrm{g}}$ & $0.321 \pm 0.001^{\mathrm{b}}$ \\
\hline US + pH2 & $28.65 \pm 0.071^{\mathrm{g}}$ & $1341.25 \pm 0.35^{\mathrm{k}}$ & $0.315 \pm 0.001^{\mathrm{b}}$ \\
\hline US + pH4 & $25.50 \pm 0.141^{\mathrm{i}}$ & $1544.15 \pm 0.35^{\mathrm{h}}$ & $0.227 \pm 0.003^{\mathrm{e}}$ \\
\hline US + pH6 & $41.61 \pm 0.354^{\mathrm{c}}$ & $1349.35 \pm 0.35^{\mathrm{j}}$ & $0.283 \pm 0.002^{\mathrm{d}}$ \\
\hline US + pH8 & $58.72 \pm 0.028^{\mathrm{a}}$ & $1617.70 \pm 0.14^{\mathrm{b}}$ & $0.301 \pm 0.001^{\mathrm{c}}$ \\
\hline US + pH10 & $46.54 \pm 0.049^{\mathrm{b}}$ & $1718.20 \pm 0.28^{\mathrm{e}}$ & $0.342 \pm 0.001^{\mathrm{a}}$ \\
\hline US + pH12 & $11.25 \pm 0.354^{\mathrm{m}}$ & $1372.30 \pm 0.28^{\mathrm{i}}$ & $0.176 \pm 0.002^{\mathrm{g}}$ \\
\hline a-n Treatment means with the same letter in each sample are not significantly different $(p>0.05)$.
\end{tabular}

Electrophoresis (SDS-PAGE)

SDS-PAGE was used to analyze the HPC samples undergoing $\mathrm{pH}$ shifting, ultrasonication, and the combination of $\mathrm{pH}$ shifting and ultrasonication under non-reducing and reducing conditions (Figure 3 ). The identification of bands corresponding to the two major fractions found in hemp seed protein, albumins $(\sim 30 \%)$, and globulins $(\sim 60 \%)$, was based on previous studies $[45,46]$. The most prevalent protein found in the HPC is the globulin edestin which consists of six subunits with each subunit consisting of an acidic (Edestin A) and basic (Edestin B) component linked together by disulfide bonding. Specifically, bands below $18 \mathrm{kDa}$ were attributed to albumins and bands of $\sim 48$ (Edestin A/B), $\sim 46$ (7S globulin), 34 (Edestin A), 20 (Edestin B), and 18 (Edestin B) kDa, which were attributed to globulins. In all conditions, the albumins were preferentially solubilized over the globulins. $\mathrm{pH}$ shifting, especially at alkaline conditions, led to the aggregation of proteins shown by the increased staining intensity at higher molecular weights. The aggregation can be attributed to edestin due to the loss of staining intensity at $48 \mathrm{kDa}$ under non-reducing conditions.

The presence of reducing agent led to the disappearance of the higher molecular weight aggregates along with the appearance of the Edestin subunits A and B. The staining intensity of the Edestin A and B subunits was similar across all samples, further supporting that the initial aggregates at the acidic and alkaline conditions were related to Edestin. Similar results were reported by Wang et al. in 2018 in hemp protein isolate under alkaline conditions [46]. Under acidic conditions, there was the appearance of a band at $37 \mathrm{kDa}$. The band also appeared at $\mathrm{pH} \mathrm{12,} \mathrm{but} \mathrm{with} \mathrm{a} \mathrm{lower} \mathrm{intensity.} \mathrm{Acid} \mathrm{and} \mathrm{alkaline} \mathrm{conditions} \mathrm{also}$ lead to the dissociation of edestin by the increased intensity of bands at 34,20 , and $18 \mathrm{kDa}$. The addition of ultrasonication led to an increase in staining intensity above $250 \mathrm{kDa}$ in samples shifted to $\mathrm{pH} 2,4$, and 12 . The creation of aggregates by ultrasonication agrees with previous studies done with soy, hemp, pea, and potato protein $[23,24,46]$. Based

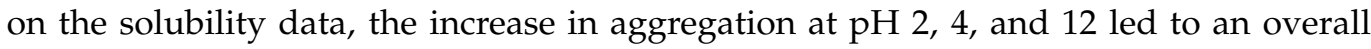


decrease in solubility compared to the control or ultrasonication only samples. Addition of ultrasonication led to an increase in the solubility of samples shifted to $\mathrm{pH} 8$ and $\mathrm{pH} 10$ over that of the $\mathrm{pH}$ shifted only samples. However, there is no significant difference in the electrophoretic profile between the samples shifted to $\mathrm{pH} 8$ and $\mathrm{pH} 10$ with or without ultrasonication.

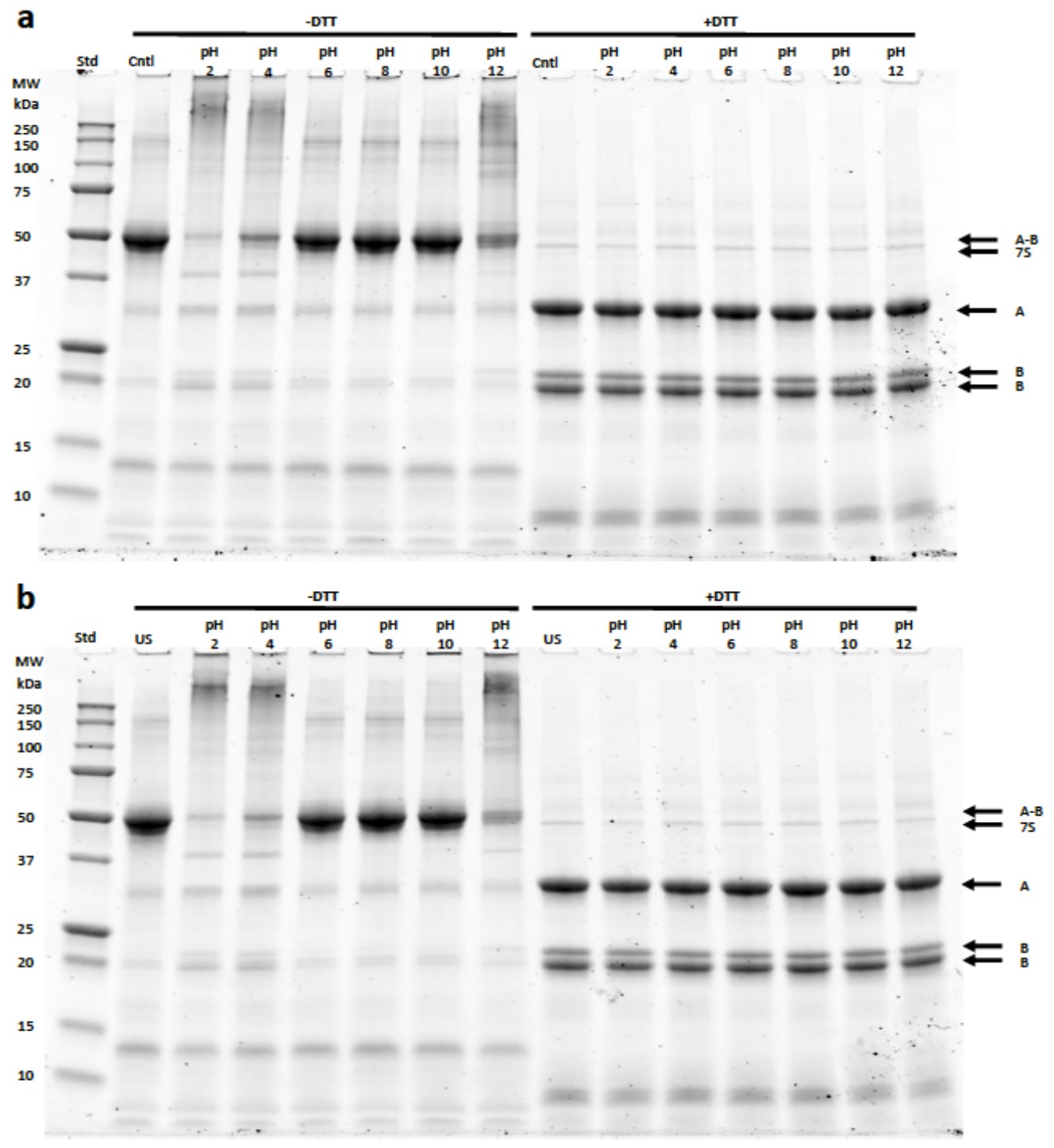

Figure 3. SDS-PAGE profile of HPC following $\mathrm{pH}$ shifting alone (a) and HPC following treatment with the combination of US with $\mathrm{pH}$ shifting (b). Samples were prepared with (+DTT) or without (-DTT). Std: molecular weight marker (kDa). HPC constituents: A/B (48 kDa) for Edestin; A, the acidic subunit (34 kDa), B, the basic subunit (20 and $188 \mathrm{kDa}$ ) for Edestin; 7S (46 kDa) for 7S globulin.

\subsection{Free Sulfhydryl Group Analysis}

Free sulfhydryl content of proteins is one of the fundamental properties that affects the functional properties (gelling, emulsifying, foaming, etc.) of protein and it is an important index to evaluate the conformation change of proteins [20,47-49]. As shown in Table 2, compared with the control, the amount of free sulfhydryl content of HPC treated with only ultrasonication increased from $32.8 \mu \mathrm{mol} / \mathrm{g}$ to $40.68 \mu \mathrm{mol} / \mathrm{g}$. Similarly, the free sulfhydryl content of ultrasonication assisted $\mathrm{pH}$ shifting treated samples at $\mathrm{pH}$, 8 , and 10 also increased significantly $(p<0.05)$ to $41.6,58.72$, and $46.54 \mu \mathrm{mol} / \mathrm{g}$ from $32.8 \mu \mathrm{mol} / \mathrm{g}$, respectively. These samples also had a higher solubility than other samples, which shows that the increase in free sulfhydryl content contributed to better solubility. 
On the other hand, $\mathrm{pH}$ shifting only treatments showed that the concentration of the free sulfhydryl group increased gradually from $\mathrm{pH} 4$ to $\mathrm{pH} 10$. According to Jiang et al. [26] and Tan et al. [50], the increase in free sulfhydryl content might be associated with the increasing intramolecular disulfide bond cleavage reactions as the media becomes more alkaline. On the contrary, adjustment of the protein solution to $\mathrm{pH} 12$ significantly reduced $(p<0.05)$ the free sulfhydryl content which might be due to the generation of disulfide bonds by sulfhydryl oxidation and interchange reactions between sulfhydryl and disulfide groups at extreme alkaline $\mathrm{pH}$ levels [26].

The results showed here concerning the free sulfhydryl content changes for ultrasonication assisted samples agreed well with those presented by Lee et al. [24], Malik et al. [16], and Xiong et al. [31], who also found a greater number of free sulfhydryl groups in sonicated samples of acidified soy protein isolate, sunflower protein isolate, and pea protein isolate. The acoustic cavitation causes breakdowns between the disulfide bonds and leads to an increase in free sulfhydryl content at the surface of the protein samples after ultrasonication treatments [48]. In contradiction to these studies, a significant decrease in free sulfhydryl groups by sonication treatments was also found on cod protein [51] and squid mantle proteins [52]. The reason of this decrease might be because of the oxidation of disulfide bonds with hydrogen peroxide molecules that formed by the generation of free radicals during sonication. This could explain the decreasing trend of ultrasound assisted $\mathrm{pH}$ shifting samples from $32.8 \mu \mathrm{mol} / \mathrm{g}$ to $28.65,25.5$, and $11.25 \mu \mathrm{mol} / \mathrm{g}$ at $\mathrm{pH} 2,4$, and 12 , respectively.

\subsection{Optical Characterization}

The turbidity and color ( $\mathrm{L}^{*}$ (lightness), $\mathrm{a}^{*}$ (redness), $\mathrm{b}^{*}$ (yellowness), chroma, and hue angle) values of the samples treated with only ultrasonication, only $\mathrm{pH}$ shifting, ultrasonication with $\mathrm{pH}$ shifting, and non-treated were shown in Tables 2 and 3, respectively. In general, the samples treated with only $\mathrm{pH}$ shifting had significantly higher $\mathrm{L}^{*}$ values, and lower $\mathrm{a}^{*}$ and $\mathrm{b}^{*}$ values than the HPC samples treated with ultrasonication $(p<0.05)$.

Table 3. Color values of non-treated and treated HPC samples.

\begin{tabular}{cccc}
\hline & L $^{*}$ & $\mathbf{a}^{*}$ & $\mathbf{b}^{*}$ \\
\hline Control & $89.350 \pm 0.78^{\mathrm{e}}$ & $-0.060 \pm 0.01^{\mathrm{bc}}$ & $4.110 \pm 0.01^{\mathrm{a}}$ \\
\hline $\mathrm{pH} 2$ & $94.855 \pm 0.01^{\mathrm{b}}$ & $-0.275 \pm 0.04^{\mathrm{ef}}$ & $1.450 \pm 0.06^{\mathrm{g}}$ \\
\hline $\mathrm{pH} 4$ & $95.845 \pm 0.05^{\mathrm{a}}$ & $-0.245 \pm 0.02^{\mathrm{e}}$ & $0.920 \pm 0.01^{\mathrm{h}}$ \\
\hline $\mathrm{pH} 6$ & $93.130 \pm 0.04^{\mathrm{c}}$ & $-0.320 \pm 0.01^{\mathrm{fg}}$ & $2.405 \pm 0.04^{\mathrm{c}}$ \\
\hline $\mathrm{pH} 8$ & $93.655 \pm 0.05^{\mathrm{c}}$ & $-0.160 \pm 0.01^{\mathrm{d}}$ & $1.635 \pm 0.04^{\mathrm{f}}$ \\
\hline pH10 & $92.895 \pm 0.02^{\mathrm{c}}$ & $-0.020 \pm 0.00^{\mathrm{b}}$ & $3.135 \pm 0.02^{\mathrm{b}}$ \\
\hline pH12 & $92.015 \pm 0.02^{\mathrm{d}}$ & $-0.105 \pm 0.01^{\mathrm{cd}}$ & $3.160 \pm 0.03^{\mathrm{b}}$ \\
\hline US_Only & $83.140 \pm 0.06^{\mathrm{h}}$ & $0.295 \pm 0.02^{\mathrm{a}}$ & $3.075 \pm 0.04^{\mathrm{b}}$ \\
\hline US + pH2 & $87.880 \pm 0.04^{\mathrm{f}}$ & $-0.440 \pm 0.01^{\mathrm{h}}$ & $1.770 \pm 0.03^{\mathrm{e}}$ \\
\hline US + pH4 & $88.385 \pm 0.05^{\mathrm{f}}$ & $-0.360 \pm 0.01^{\mathrm{g}}$ & $1.370 \pm 0.03^{\mathrm{gh}}$ \\
\hline US + pH6 & $86.120 \pm 0.03^{\mathrm{g}}$ & $-0.475 \pm 0.01^{\mathrm{h}}$ & $1.460 \pm 0.03^{\mathrm{g}}$ \\
\hline US + pH8 & $89.910 \pm 0.04^{\mathrm{e}}$ & $-0.675 \pm 0.02^{\mathrm{i}}$ & $1.280 \pm 0.01^{\mathrm{h}}$ \\
\hline US + pH10 & $82.740 \pm 0.06^{\mathrm{h}}$ & $-0.690 \pm 0.01^{\mathrm{i}}$ & $2.020 \pm 0.01^{\mathrm{d}}$ \\
\hline US + pH12 & $90.165 \pm 0.09^{\mathrm{e}}$ & $-0.160 \pm 0.03^{\mathrm{d}}$ & $1.265 \pm 0.02^{\mathrm{h}}$ \\
\hline
\end{tabular}

$\overline{\mathrm{a}-\mathrm{i}}$ Treatment means with the same letter in each sample are not significantly different $(p>0.05)$.

In accordance with the trends observed in color values, the turbidity of samples treated with $\mathrm{pH}$ shifting alone was the lowest among all samples. Turbidity could be defined as a function of the number and size of particles that dispersed in a dispersion [48]. Therefore, 
the number and size of soluble hemp protein aggregated in the mixture has a considerable effect on turbidity. In this study, the samples treated with the combination of ultrasonication and $\mathrm{pH}$ shifting had a significantly $(p<0.05)$ higher turbidity value than the samples treated with $\mathrm{pH}$ shifting alone. The collected data showed that the ultrasound applied samples had a higher solubility compared to other treated and control samples, which led the samples to have higher turbidity than others. This might be due to the disintegrating effect of ultrasound on soluble particles. Similarly, in the study of Jiang et al. [26], a significant increase in the turbidity values of commercial soy protein isolate was observed after being treated with sonication at the frequency of $20 \mathrm{kHz}$.

\section{Conclusions}

In the current work, the effects of ultrasonication $(20 \mathrm{kHz})$ and $\mathrm{pH}$ shifting applications on the physicochemical and functional properties of HPC were investigated. Compared to ultrasonication and $\mathrm{pH}$ shifting alone treatments, their combination at alkaline $\mathrm{pH}$ levels worked synergistically and showed a significant improvement in the physicochemical and functional properties of HPC. The solubility of the samples was significantly improved by a combined treatment of $\mathrm{pH}$ shifting and ultrasonication with an increase from up to $1718.20 \mu \mathrm{g} / \mathrm{mL}$ from $1442.75 \mu \mathrm{g} / \mathrm{mL}$. Additionally, the results indicated that the surface hydrophobicity of HPC could be enhanced almost $60 \%$ with the ultrasonication alone treatment. The particle size and polydispersity index of HPC dispersions also reduced significantly $(p<0.05)$ from $1.05 \pm 0.05 \mathrm{~mm}$ to $0.33 \pm 0.02 \mathrm{~mm}$, and from $55.9 \pm 1.2 \%$ to $12.1 \pm 0.02 \%$ after the combination of $\mathrm{pH}$ shifting at $\mathrm{pH} 4$ and ultrasonication treatment, respectively. The results of this study demonstrated that the application of ultrasonication and $\mathrm{pH}$ shifting combined treatment might be an effective alternative method for protein modification.

Author Contributions: Conceptualization, O.K., G.E.P. and C.F.; data curation, O.K.; formal analysis, O.K. and G.E.P.; methodology, O.K. and G.E.P.; software, O.K.; visualization, O.K.; writing-original draft, O.K.; writing-review \& editing, G.E.P. and C.F. All authors have read and agreed to the published version of the manuscript.

Funding: This research received no external funding.

Institutional Review Board Statement: Not applicable.

Informed Consent Statement: Not applicable.

Data Availability Statement: Despite all information has been provided herein, raw data are available upon request to the corresponding author.

Conflicts of Interest: O.K., G.E.P., C.F. are employees of Applied Food Sciences Inc. Applied Food Sciences provided the funding and materials for this study. The company's authors had no influence on the correctness and fairness of the research results.

\section{References}

1. WHO Expert Consultation. Protein and amino acid requirements in human nutrition. In World Health Organization Technical Report Series; World Health Organization: Geneva, Switzerland, 2007; Volume 935, pp. 1-265.

2. Galanakis, C.M. Functionality of food components and emerging technologies. Foods 2021, 10, 128. [CrossRef]

3. FAO. The State of Food Security and Nutrition in the World. Available online: www.fao.org.http://www.fao.org/state-of-foodsecurity-nutrition/en/ (accessed on 13 February 2021).

4. Clark, M.A.; Domingo, N.G.; Colgan, K.; Thakrar, S.K.; Tilman, D.; Lynch, J.; Azevedo, I.L.; Hill, J.D. Global food system emissions could preclude achieving the $1.5^{\circ}$ and $2^{\circ} \mathrm{C}$ climate change targets. Science 2020, 370, 705-708. [CrossRef] [PubMed]

5. Shen, P.; Gao, Z.; Fang, B.; Rao, J.; Chen, B. Ferreting out the secrets of industrial hemp protein as emerging functional food ingredients. Trends Food Sci. Technol. 2021, 112, 1-15. [CrossRef]

6. Tang, C.H.; Ten, Z.; Wang, X.S.; Yang, X.Q. Physicochemical and functional properties of hemp (Cannabis sativa L.) protein isolate. J. Agric. Food Chem. 2006, 54, 8945-8950. [CrossRef]

7. Wu, G.; Meinninger, C.J. Regulation of nitric oxide synthesis by dietary factors. Annu. Rev. Nutr. 2002, 22, 61-86. [CrossRef]

8. Zhou, Y.; Danbolt, N.C. Glutamate as a neurotransmitter in the healthy brain. J. Neural Transm. 2014, 121, 799-817. [CrossRef] [PubMed] 
9. House, J.D.; Neufeld, J.; Leson, G. Evaluating the quality of protein from hemp seed (Cannabis sativa L.) products through the use of the protein digestibility-corrected amino acid score method. J. Agric. Food Chem. 2010, 58, 11801-11807. [CrossRef]

10. Shen, P.; Gao, Z.; Xu, M.; Rao, J.; Chen, B. Physicochemical and structural properties of proteins extracted from dehulled industrial hempseeds: Role of defatting process and precipitation pH. Food Hydrocoll. 2020, 108, 106065. [CrossRef]

11. Wang, X.S.; Tang, C.H.; Li, B.S.; Li, L.; Yang, X.Q.; Ma, C.Y. Effects of high pressure treatment on some physicochemical and functional properties of soy protein isolates. Food Hydrocoll. 2008, 22, 560-567. [CrossRef]

12. Tang, C.H.; Wang, X.Y.; Yang, X.Q.; Lin, L. Formation of soluble aggregates from insoluble commercial soy protein isolate by means of ultrasonic treatment and their gelling properties. J. Food Eng. 2009, 92, 432-437. [CrossRef]

13. Guo, C.; Zhang, Z.; Chen, J.; Fu, H.; Subbiah, J.; Chen, X.; Wang, Y. Effects of radio frequency heating treatment on structure changes of soy protein isolate for protein modification. Food Bioprocess Technol. 2017, 10, 1574-1583. [CrossRef]

14. Kahraman, O.; Lee, H.; Zhang, W.; Feng, H. Manothermosonication (MTS) treatment of apple-carrot juice blend for inactivation of Escherichia coli 0157:47. Ultrason. Sonochem. 2017, 38, 820-828. [CrossRef] [PubMed]

15. Jambrak, A.R.; Mason, T.J.; Lelas, V.; Herceg, Z.; Herceg, L.J.I. Effect of ultrasound treatment on solubility and foaming properties of whey protein suspensions. J. Food Eng. 2008, 86, 281-287. [CrossRef]

16. Malik, M.A.; Sharma, H.K.; Saini, C.S. High intensity ultrasound treatment of protein isolate extracted from dephenolized sunflower meal: Effect on physicochemical and functional properties. Ultrason. Sonochem. 2017, 39, 511-519. [CrossRef] [PubMed]

17. Sun, Y.; Chen, J.; Zhang, S.; Li, H.; Lu, J.; Liu, L.; Ulukoa, H.; Su, Y.; Cui, W.; Ge, W.; et al. Effect of power ultrasound pre-treatment on the physical and functional properties of reconstituted milk protein concentrate. J. Food Eng. 2014, 124, 11-18.

18. Shen, X.; Fang, T.; Gao, F.; Guo, M. Effects of ultrasound treatment on physicochemical and emulsifying properties of whey proteins pre- and post-treatment aggregation. Food Hydrocoll. 2017, 63, 668-676. [CrossRef]

19. Amiri, A.; Sharifian, P.; Soltanizades, N. Application of ultrasound treatment for improving the physicochemical, functional and rheological properties of myofibtillar proteins. International J. Biol. Macromol. 2018, 111, 139-147. [CrossRef]

20. Wang, Y.; Wang, Y.; Li, K.; Bai, Y.; Li, B.; Xu, W. Effect of high intensity ultrasound on physicochemical, interfacial and gel properties of chickpea protein isolate. LWT-Food Sci. Technol. 2020, 129, 109563. [CrossRef]

21. Ranjha, M.M.A.N.; Irfan, S.; Lorenzo, J.M.; Shafique, B.; Kanwal, R.; Pateiro, M.; Arshad, R.N.; Wang, L.; Nayik, G.A.; Roobab, U.; et al. Sonication, a potential technique for extraction of phytoconstituents: A systematic review. Processes 2021, 9, 1406. [CrossRef]

22. Jiang, J.; Wang, Q.; Xiong, Y.L. A pH shift approach to the improvement of interfacial properties of plant seed proteins. Curr. Opin. Food Sci. 2018, 19, 50-56. [CrossRef]

23. Mao, C.; Wu, J.; Zhang, X.; Ma, F.; Cheng, Y. Improving the solubility and digestibility of potato protein with an online ultrasound-assisted pH shifting treatment at medium temperature. Foods 2020, 9, 1908. [CrossRef] [PubMed]

24. Lee, H.; Yildiz, G.; Dos Santos, L.C.; Jiang, S.; Andrade, J.E.; Engeseth, N.J.; Feng, H. Soy protein nano-aggregates with improved functional properties prepared by sequential $\mathrm{pH}$ treatment and ultrasonication. Food Hydrocoll. 2016, 55, 200-209. [CrossRef]

25. Zhang, L.; Pan, Z.; Shen, K.; Cai, X.; Zheng, B.; Miao, S. Influence of ultrasound-assisted alkali treatment on the structural properties and functionalities of rice protein. J. Cereal Sci. 2018, 79, 204-209. [CrossRef]

26. Jiang, S.; Ding, J.; Andrade, J.; Rababah, T.M.; Almajwal, A.; Abulmeaty, M.M. Modifying the physicochemical properties of pea protein by $\mathrm{pH}$-shifting and ultrasound combined treatments. Ultrason. Sonochem. 2017, 38, 835-842. [CrossRef]

27. Guzel, B.H.; Arroyo, C.; Condón, S.; Pagán, R.; Bayindirli, A.; Alpas, H. Inactivation of Listeria monocytogenes and Escherichia coli by ultrasonic waves under pressure at nonlethal (manosonication) and lethal temperatures (manothermosonication) in acidic fruit juices. Food Bioprocess Tech. 2014, 7, 1701-1712. [CrossRef]

28. Misono, T.; Dynamic Light Scattering (DLS); Abe, M. (Eds.) Measurement Techniques and Practices of Colloid and Interface Phenomena; Springer: Singapore, 2019; pp. 65-69.

29. Pathare, B.; Opara, U.L.; Al-Said, F.A.-J. Colour Measurement and Analysis in Fresh and Processed Foods: A Review. Food Bioprocess. Technol. 2013, 6, 36-60. [CrossRef]

30. Kato, A.; Nakai, S. Hydrophobicity determined by a fluorescence probe method and its correlation with surface properties of proteins. Biochim. Biophys. Acta (BBA)-Protein Struct. 1980, 624, 13-20. [CrossRef]

31. Beveridge, T.; Toma, S.J.; Nakai, S. Determination of SH- and SS- groups in some food proteins using Ellman's reagent. J. Food Sci. 1974, 39, 49-51. [CrossRef]

32. Li, Y.; Cheng, Y.; Zhang, Z.; Wang, Y.; Mintah, B.K.; Dabbour, M.; Jiang, H.; He, R.; Ma, H. Modification of rapeseed protein by ultrasound-assisted $\mathrm{pH}$ shift treatment: Ultrasonic mode and frequency screening, changes in protein solubility and structural characteristics. Ultrason. Sonochem. 2020, 69, 105240. [CrossRef]

33. Liang, Q.; Ren, X.; Qu, W.; Zhang, X.; Cheng, Y.; Ma, H. The impact of ultrasound duration on the structure of $\beta$-lactoglobulin. J. Food Eng. 2021, 292, 110365. [CrossRef]

34. Zhang, Z.H.; Regenstein, J.M.; Zhou, P.; Yang, Y.L. Effects of high intensity ultrasound modification on physicochemical property and water in myofibrillar protein gel. Ultrason. Sonochem. 2017, 34, 960-967. [CrossRef] [PubMed]

35. Zhu, Z.; Zhu, W.; Yi, J.; Liu, N.; Cao, Y.; Lu, J.; Decker, E.A.; McClements, D.J. Effects of sonication on the physicochemical and functional properties of walnut protein isolate. Food Res. Int. 2018, 106, 853-861. [CrossRef] [PubMed]

36. Wen, C.; Zhang, J.; Yao, H.; Zhou, J.; Duan, Y.; Zhang, H.; Ma, H. Advances in renewable plant-derived protein source: The structure, physicochemical properties affected by ultrasonication. Ultrason. Sonochem. 2019, 53, 83-98. [CrossRef] [PubMed] 
37. Jambrak, A.R.; Lelas, V.; Mason, T.J.; Kresic, G.; Badanjak, M. Physical properties of ultrasound treated soy proteins. J. Food Eng. 2009, 93, 386-393. [CrossRef]

38. Parada, I.A.; Arreola, W.T.; Jimenez, G.M.S.; Suarez, J.C.R.; Onofre, J.E.J.; Felix, F.R.; Rios, E.M. Effect of ultrasound on physicochemical and foaming properties of protein concentrate from giant squid (Dosidicus gigas) mantle. LWT-Food Sci. Technol. 2020, 121, 108954. [CrossRef]

39. Yang, F.; Liu, X.; Ren, X.E.; Huang, Y.; Huang, C.; Zhang, K. Swirling cavitation improves the emulsifying properties of commercial soy protein isolate. Ultrason. Sonochem. 2018, 42, 471-481. [CrossRef]

40. Xiong, T.; Xiong, W.; Ge, M.; Xia, J.; Li, B.; Chen, Y. Effect of high intensity ultrasound on structure and foaming properties of pea protein isolate. Food Res. Int. 2018, 109, 260-267. [CrossRef]

41. Gui, Y.; Li, J.; Zhu, Y.; Guo, L. Roles of four enzyme crosslinks on structural, thermal and gel properties of potato proteins. LWT-Food Sci. Technol. 2020, 123, 109116. [CrossRef]

42. Huang, L.; Ding, X.; Li, Y.; Ma, H. The aggregation, structures and emulsifying properties of soybean protein isolate induced by ultrasound and acid. Food Chem. 2019, 279, 114-119. [CrossRef]

43. Gao, D.; Helikh, A.; Duan, Z. Determining the effect of ph-shifting treatment on the solubility of pumpkin seed protein isolate. East. -Eur. J. Enterp. Technol. 2021, 5, 29-34. [CrossRef]

44. Jiang, L.; Wang, J.; Li, Y.; Wang, Z.; Liang, J.; Wang, R.; Chena, Y.; Ma, W.; Qi, B.; Zhang, M. Effects of ultrasound on the structure and physical properties of black bean protein isolates. Food Res. Int. 2014, 62, 595-601. [CrossRef]

45. Kim, J.; Lee, M.Y. Isolation and characterization of edestin from Cheungsam hempseed. J. Appl. Biol. Chem. 2011, 54, 84-88. [CrossRef]

46. Wang, Y.J.; Xiong, Y.L. Heating-aided $\mathrm{pH}$ shifting modifies hemp seed protein structure, cross-linking, and emulsifying properties. J. Agric. Food Chem. 2018, 66, 10827-10834. [CrossRef] [PubMed]

47. Zhou, M.; Liu, J.; Zhou, Y.; Huang, X.; Liu, F.; Pan, S. Effect of high intensity ultrasound on physicochemical and functional properties of soybean glycinin at different ionic strengths. Innov. Food Sci. Emerg. Technol. 2016, 34, 205-213. [CrossRef]

48. Gharibzahedi, S.M.; Smith, B. The functional modification of legume proteins by ultrasonication: A review. Trends Food Sci. Technol. 2020, 98, 107-116. [CrossRef]

49. Xu, Y.J.; Dong, M.; Tang, C.B.; Han, M.Y.; Xu, X.L.; Zhou, G.H. Glycation-induced structural modification of myofibrillar protein and its relation to emulsifying properties. LWT_Food Sci. Technol. 2020, 117, 108664. [CrossRef]

50. Tan, M.; Xu, J.; Gao, H.; Yu, Z.; Liang, J.; Mu, D.; Li, X.; Zhong, X.; Luo, S.; Zhao, Y.; et al. Effects of combined high hydrostatic pressure and $\mathrm{pH}$-shifting pretreatment on the structure and emulsifying properties of soy protein isolates. J. Food Eng. 2021, 306, 110622. [CrossRef]

51. Ma, W.; Wang, J.; Xu, X.; Qin, L.; Wu, C.; Du, M. Ultrasound treatment improved the physicochemical characteristics of cod protein and enhanced the stability of oil-in-water emulsion. Food Res. Int. 2019, 121, 247-256. [CrossRef]

52. Barraza, O.A.H.; Arreola, W.T.; Brauer, J.M.E.; Moroyoqui, F.J.C.; Figueroa, J.C.R.; Rios, E.M. Effect of pulsed ultrasound on the physicochemical characteristics and emulsifying properties of squid (Dosidicus gigas) mantle proteins. Ultrason. Sonochem. 2017, 38, 829-834. [CrossRef] 